\title{
Digital Role-Playing Games as Artefacts of Media Culture
}

\section{Jana Radošinská}

(Doctor of Philosophy, Department of Mass Media Communication, Faculty of Mass Media Communication, University of SS. Cyril and Methodius in Trnava, Námestie J. Herdu 2, 91701 Trnava, Slovakia), Email: jana.radosinska@ucm.sk

\section{Doi:10.5901/mjss.2016.v7n2p368}

\begin{abstract}
Cultural significance of digital role-playing games is associated with dynamic emergence of communication technologies, media entertainment and new - digital - forms of cultural production. However, computer (digital) role-playing games (also called cRPGs) are, mainly in case of scholarly analyses and existing theoretical concepts, often compared to other, mostly live forms of role-playing. The academic reflections on undeniable differences between various types of role-playing tend to suggest that computer role-playing, even though it is a (financially as well as culturally) significant part of the digital games industry, is just a less diverse form of role-play that lacks both formal variety and content ingenuity and thus cannot be used as a tool for socialisation, education or therapy. The article, however, works with a basic assumption that the relationship between contemporary subcultures (or rather taste cultures and lifestyles), entertainment forms, computer role-playing games and the everyday lives of media audiences includes a complex set of aspects and specific features which are socially significant and rich in both form and content. The author focuses on defining digital role-playing games in relation with industrially produced culture, which is disseminated by the media, and argues that they are able to function not only as commercially efficient media products but also as valuable cultural artefacts. The main goal of the text is to offer complex theoretical outlines related to understanding computer role-playing and its cultural significance.
\end{abstract}

Keywords: computer role-playing games, media culture, transmedia narrative, fantasy, media entertainment

\section{Introduction}

Popularity of computer role-playing games is, in our opinion, associated with their specific ability to combine everincreasing technological perfection and visual dynamics of their own virtual environments with narrative features that are based on cultural traditions and rituals - storylines of these games often refer to traditions that have been inherent parts of the human civilisation since its earliest phases. All forms of role-playing are somehow instinctive, built upon the human nature in order to integrate children's tendency to imitate their parents' behaviour or manners of celebrities (i.e. their idols, role models) with certain aspects of timeless heroic stories which are, and always have been, parts of all cultures and societies. However, any statements which suggest that role-playing, as a human activity, is entirely a matter of children and teenagers are necessarily false. These games, regardless of their varying forms, offer stories that - implicitly or explicitly - involve myths, rituals as well as archetypes that allow these gamers to access universal experience related to the world, society, individual life and culture.

As S. L. Bowman (2010) points out, role-playing games offer an ideal opportunity to form alternative identities actively; this kind of safe self-exploration allows to embrace the hidden aspects of one's own personality, often constrained or suppressed in the 'ordinary' life in order to be in accordance with the rules enforced by the dominant (mainstream) culture. The everyday reality makes people concentrate their attention on the demands of their common social roles. Role-playing games thus offer a rare chance to let one's fantasy flow freely, without any constraints. Moreover, such an activation of - mostly hidden and suppressed - aspects of human personality and imagination results in a very empowering experience - regardless of whether we actually realise the existing intrinsic need for symbolic selfexploration or not.

Even though single-player computer role-playing games do not primarily offer their users opportunities to engage in direct social interaction and interactive exchange of information is thus limited to the individual player and virtual game environment (computers or any other digital gaming devices, e.g. video game consoles such as Playstation), these games, nevertheless, may be interactive and rich in terms of players' opportunities to influence the main storyline and employ different options and choices. J. Malíček (2008) states that digital role-playing game is a kind of video game which is based on controlling a story and adventure of a group of video game characters (a party). The player, who is also personified into the main character (hero), assumes the position of "someone watching above" and leads the small 
team (group or party), experiencing different stories, circumstances, worlds, surroundings, engaging in physical, psychological and magical (or technological) fights against the enemies. These games, as the author says, also tend to involve solving puzzles and riddles, acquiring rewards, trophies and information that are necessary to access the next part of the story.

Another basic definition of digital RPGs, as offered by M. Maličková (2008), mentions one of the most significant limitations of this kind of entertainment - in comparison with, for example, live-action role-playing, also called LARP - its inability to create and personally (physically) experience a full-fledged, complex and unique story live, in real time. Instead, computer role-playing games uncover, step by step, prearranged scenarios. The author calls this basic feature of cRPGs "successive elimination of staging processes" (p. 58). Virtual single-player role-playing is, more or less, staged by its authors (producers and writers); the games often work with several different variants of experiencing the stories and diverse outcomes, providing their players with a chance to become the active users who individually choose between the existing scenarios and experience one of them.

In this context, it should be mentioned that, if we apply a certain amount of simplification with regard to existing and ever-transforming digital game genres, we may differentiate between two different kinds of computer role-playing games. Besides the above-mentioned single-player RPGs, there are also so called MMORPGs (massively multiplayer online roleplaying games). MMORPGs may be defined as multi-player games that require Internet connection - their interactive potential lies in communication between the player and the virtual environment as well as in communication between the players themselves. It is necessary to point out that there are various types of multi-user online games and MMORPGs are just one of the existing forms. Direct social interaction related to multi-user online games is bound to the moments when the players 'pass through' the boundaries of ordinary reality and assume their imaginary - often heroic - identities.

Even though the massive worldwide popularity of MMORPG World of Warcraft and similar games is the best possible proof of both commercial value and cultural significance of this kind of virtual games, we would like to suggest that single-player RPGs may as well - and often do - achieve almost cult status and thus become artefacts of media culture. However, in certain cases it is appropriate to argue that defining digital 'offline' games such as the Mass Effect series (BioWare, 2008, 2010, 2012) as computer RPGs is relevant mostly in the context of their commercial potential rather than in terms of their narrative features and game design. These and similar games involve various role-playing elements but, on the other hand, the players are not able to finish the stories in accordance with their own imagination, i.e. it is impossible to ignore the pre-staged scenarios and outcomes and 'go one's own way'. Considering this fact, most single-player RPGs are rather adventure games or action games enriched by the role-playing elements in order to provide their players (users) with deeper emotional engagement with the heroic stories they tell. However, the thematic focus of this article does not necessarily presume employment of the sharp distinctions between various forms of digital role-playing. Instead of that, we focus our attention on digital role-playing games (or rather role-playing elements included in video games) and their place within the system of industrially produced culture disseminated by media, i.e. media culture.

\section{Thematic and Genre Aspects of Contemporary Digital Role-Playing Games}

The most attractive attribute of any digital single-player (offline) role-playing games is the opportunity to influence the aspects of its narrative lines that offer various outcomes and choices - to engage in imaginary relationships (i.e. symbolic interaction) with virtual companions, explore fictional environments, identify with the avatar (the hero of the story), modify the hero's features, appearance, armour, abilities and often even 'psychological profile' - in case various moral choices and secondary storylines (e.g. romances or rather so called love interests) are available to choose from. This game concept mostly aims to offer various experiences which are associated with exploration of the imaginary fantastic places and thus unachievable in the real world. The fictitious heroes of role-playing games may even become 'virtual extensions' of players in terms of self-identification. As much as these matters should be discussed by placing emphasis on the concept of symbolic interaction, we may also address the issue through M. McLuhan's (2000) world-renowned understanding of (in our case, digital) media as the extensions of man.

Although, at least when compared to MMORPGs or other forms of role-playing involving virtual form of socialisation and cooperation, offline (single-player) computer role-playing games are not based on 'real' social communication and interaction between the players, it is certainly interesting to focus on their commercial value and position within the digital game industry or entertainment industry as a whole. Currently, the role-playing elements seem to be effective aspects of video games that strongly influence their stories as well as gameplays. The digital era we live in unfolds many innovative opportunities to intensify the digital (virtual) gaming experience. As a general rule, the most popular - and commercially successful - computer games, including CRPGs, are able to fulfil the expectations and 
preferences of their target audiences.

The above-mentioned diversity of role-playing forms, online and offline, suggests that even single-player digital RPGs (moreover, many of them do include also multi-player modes, i.e. online modes) tend to explore the possibilities of genre hybridisation in order to meet diverse expectations of potential players. Although being so different from many other kinds of media culture products (e.g. television shows, Hollywood blockbusters, articles in magazines), single-player computer role-playing games seem to become widely popular under the same circumstances - the contemporary trends in media production routinely employ genre hybridisation, innovative elements of interaction, spectacular visuals and heroic stories in order to attract the audiences (or users) and keep them engaged.

The increasing popularity of digital role-playing games is primarily linked to dynamic changes in cultural paradigm that have been influencing life in developed liberal-democratic countries since the emergence and commercial use of the Internet and digital media. S. L. Bowman (2010) sees the technological development of communication devices as one of the main factors shaping the current cultural environment but, on the other hand, she also notes that late-modern man, surrounded by the advanced communication technologies, often seeks for "alternative lifestyles" and is therefore interested in fantastic fiction - magic, science-fiction, horror.

Digital role-playing games have become a diversifying form of media culture mostly thanks to the duality mentioned above - they represent new trends in popular culture and their strengthening connection to virtual reality and cyberspace, as well as long-lived ways of ritual behaviour which is, in many different forms and versions, natural for the whole humankind. We may even assume that all kinds of role-playing, whether digital or experienced physically, allow participants (users, players, actors) to fulfil their need for engaging in late-modern forms of rituals which react to contemporary social and cultural reality. Such opportunities may lead to developing one's own imagination and fantasy these aspects of human intrinsic feelings are often suppressed, mostly because of their apparent insignificance and uselessness in the context of ordinary life (work, school, household chores). Many other kinds of media entertainment and cultural products, especially those which may be seen as rather passive, simply cannot offer their audiences (i.e. consumers) so much creative space for releasing inner energy and fulfilling spiritual needs.

Most digital role-playing games involve heroic stories that are based on wholly fictional worlds or alternative realities. However, a few of them also offer various imaginations of anti-utopic past, presence or future or, eventually, experiment with entirely different themes and motives and are therefore hard to categorise. Such complex and visually compelling fictive realities, thanks to dynamic development of computer-generated imagery, three-dimensional modelling, motion-capturing and game design, seem to be utterly real - mainly in the moments of playing the games. The imaginary realities associated with digital role-playing games and their narratives are often highly developed and convincing. These fantasy worlds have their own rules and laws, history, geography, often even language and mythology that make the storylines seem very authentic and comprehensive. The only and key aspect which makes them fantastic and thus unreal is the fact that they do not exist physically. Middle Earth (The Lord of the Rings by John R. R. Tolkien), the 'galaxy far, far away' (George Lucas's Star Wars), Star Trek universe, Narnia (The Chronicles of Narnia by C. S. Lewis) or lately Westeros (The Game of Thrones written by George R. R. Martin and developed for television by HBO) are probably the most famous fantasy worlds of contemporary popular culture but there are many, many more.

If we consider the digital role-playing games, it is appropriate to mention Skyrim (The Elder Scrolls V: Skyrim, Bethesda Game Studios, 2011), Warcraft (World of Warcraft, Blizzard Entertainment, 2004), Mass Effect universe (BioWare, 2008, 2010, 2012), Thedas (Dragon Age series, BioWare, 2009, 2011, 2014) and so on. For example, Thedas, a medieval-like continent, may be seen as a convincing fantasy world, which is inhabited by humans, mages, Templars as well as various humanoid races - e.g. elves, Qunari, Avvar. It is obvious that most of these fantasy worlds have appeared (or will appear in the future) in lots of different media products - literature, TV shows, films, graphic novels, comic books, etc. On the other hand, other fictional universes, such as the Star Wars universe, were successfully adapted to the form of digital role-playing games, e.g. Knights of the Old Republic (BioWare, 2003).

Quite a few cRPGs have achieved massive popularity, appealed to a significant amount of fans, presented especially iconic heroes or contributed to the whole game industry by introducing innovative technologies, game mechanisms, game engine modifications or original stories. Moreover, some of these games have become global cultural phenomena, other have achieved 'only' rather modest popularity or small-but-intense cult followings. Their success is not related only to thorough and carefully managed promotion and marketing strategies employed by their producers and distributors. In J. Fiske's words (2010), all forms of popular culture, whether mediated or not, have to achieve popularity by appealing to their audiences since popularity as such cannot be 'produced' by the producers themselves.

Single-player digital role-playing games are notably story-driven. As H. Jenkins (2004) remarks, not all games tell stories. Games may be an abstract, expressive, and experiential form; however, many of them do have narrative aspirations. This seems to be true also in the case of CRPGs which are, as a general rule, markedly based on engaging 
and attractive plotlines. Digital role-playing games that are widely popular involve, almost without any exceptions, genre elements associated with science-fiction and fantasy. According to T. E. Mortensen (2007), the fans of computer roleplaying games tend to mention different, very diverse reasons why they like this type of games particularly. However, most of them share the one key characteristic - they are strongly interested in cultural artefacts that are associated with science-fiction and fantasy (in both literary and film genre forms).

Moreover, it seems that the significant popularity of these fictional genres has resulted in existence and creative use of 'science-fantasy'. J. Malíček (2008) states that science-fantasy might be seen as a subgenre of science-fiction. It combines the motives and themes typical for sci-fi (intergalactic flights, space exploration, science and futuristic technology) and fantasy (magic, good vs. evil, heroic trials, aspects of mythology). This argument is impossible to disagree with - after all, digital role-playing games also frequently combine the elements of science-fiction and fantasy in order to appeal to the fans of Star Wars, Star Trek or other significantly popular cultural artefacts (e.g. Mass Effect and its portrayal of technologically advanced, but also mysterious traveling - through so called mass relays - and introduction of 'magic' or, more precisely, biotic abilities that are - in many ways - similar to the Force in the Star Wars fictional universe).

Even though fantasy genre is still widely popular and integrated into all types of RPGs and role-playing as such, the 1980s and the following decades witnessed the rise of science-fiction role-playing games, along with the business of culture and video game industry. The increasing interest in the futuristic role-playing games seems to be related to the dynamic development of information and communication technologies that are integral parts of the late-modern society. The introduction of computers and other communication technologies to the socio-cultural reality of the late $20^{\text {th }}$ century logically resulted in the need for reflecting on the ever-changing 'relationship' between human beings and modern technologies. According to S. Gálik (2014), the communication within cyberspace has influenced our cultural and social ways of life and even created a new existential dimension of man.

O. Herec (2008), the renowned Slovak literary scientist and fantasy theorist, sees science-fiction as one of the categories of modern fantastic fiction - besides fantasy and horror. These distinctions are, in Herec's words, associated with pressures of the commercial imperatives in $20^{\text {th }}$ and especially in $21^{\text {st }}$ century. Even though the characters and themes of modern fantasy fiction have been transformed and modernised, they are still directly linked to their origins folk literature and culture. Herec's concept of modern fantasy fiction also allows us to better understand science-fantasy it seems that producers in the media industry purposefully combine the elements of science-fiction, fantasy and horror, which used to be sharply distinguished, in order to attract the fans of all subgenres and keep them engaged with products that include all these thematic aspects.

It is necessary to point out that digital role-playing games work with the three above-mentioned subgenres of modern fantastic fiction - fantasy, science-fiction and horror - in various ways. Horror aspects seem to be applied least often; most mainstream cRPGs combine the elements of science-fiction and fantasy. However, there are still many digital role-playing games that may be defined solely as science-fiction games or fantasy games. One of the basic distinctions between fantasy CRPGs and sci-fi CRPGs lies in character dramaturgy. Fantasy genre tends to involve archetypes and mythical role models while science-fiction genre introduces soldiers, agents or scientists with special talents and abilities that are often based on research, knowledge and fictive technologies existing within fictive universes. Two examples of contemporary single-player action RPGs (both produced by BioWare), Dragon Age series and Mass Effect series, allow us to define such differences. The Dragon Age series is set into a quasi-medieval environment and presents various archetypal characters - e.g. mysterious mages, cunning thieves, always-funny dwarves, virtuous elves, mighty noble warriors. Each player may choose from all these classes or rather types of 'freelancers' in order to create his/her own hero, a hero to be identified with. On the other hand, sci-fi characters in Mass Effect series are introduced through military classes and scientific fields, e.g. there are soldiers; engineers; adepts, vanguards and sentinels - the characters who possess, to various extents, biotic (magical) abilities; infiltrators (snipers or spies). The 'support' characters are very diverse too and include medics, mercenaries, pilots, even annoying journalists or the hero's fanatic admirers. This gameplay variation inspires the player to pick a favourite class, creatively edit the main character's (Commander Shepard's) gender, looks, origin and determine his/her morality through a specific system of moral decisions.

However, both game subgenres have also much in common. Fantasy and science-fiction RPGs offer their players many different opportunities to experience adventure, danger, investigation or pilgrimage; both of them involve situations based on performing heroic deeds, accomplishing extraordinary results and exploring fantastic environments that are utterly different from the ordinary world. The exploration of new planets and alien races is linked to the same or similar feelings of discovering and experiencing 'the unknown' as the heroic pilgrimage situated to an idealised version of the Middle Ages. While fantasy CRPGs tend to portray fictional and fantastic versions of our world and its history, sciencefiction CRPGs might (and often do) involve also imaginary planets or galaxies. Space travels have fascinated us since the 
very first attempts to explore the Earth's surroundings and the galaxy. The second half of the $20^{\text {th }}$ century brought rapidly faster ways of traveling and communication, the modern science was able to clarify many once-incomprehensible phenomena of the nature and human existence. The mysteries of our world thus became less mysterious. This is where science-fiction 'jumps in' - human imagination, being suppressed consciously or unconsciously, is still longing for mysteries and adventures, regardless of the level of technological development. Sci-fi movies, books and video games are popular mainly because they are able to symbolically offer us new secrets and mysteries.

\section{Digital Role-Playing in Media Culture}

Cultural significance of digital role-playing games is closely related to shifts in 'western' cultural paradigm that started to manifest themselves significantly in the middle of 1960s. Besides pointing out the general changes in popular culture and individual lifestyles (e.g. youth movements, countercultural values, sexual revolution, increasing interest in mysticism and mythology), it is necessary to mention one of the most important milestones of Western popular culture - J.R. R. Tolkien's fantasy trilogy The Lord of the Rings. The massive popularity of Tolkien's literary works resulted in booming interest in fantasy literature (as a result, many other worldwide popular fantasy stories were created). S. L. Bowman (2010) refers to T. Stallone's words in order to reflect on this "modern" interest in the Middle Ages. The medieval lore and cultural elements are typically popular with the fans of fantasy genre but the purpose here is not to re-create such a world - it is rather an imaginary creation of an idealised version of the past that binds the ideas of gallantry, honour, respect, beauty and virtue without any regard to negative phenomena related to the medieval society (e.g. plague, the Inquisition).

These aspects of modern and late-modern culture need to be mentioned also in the context of the current development tendencies of media culture. As H. Pravdová, Z. Hudíková and E. Habiňáková (2014) observe, these matters are closely related to the cultural imperatives of being "IN" or "OUT". Cultural imperatives create and shape "the cult of image" by supporting the processes of uncritical worshipping and imitation. The cult of image (as a part of "IN" imperatives supported and disseminated by the media industry) seems to be one of the most effective marketing strategies. Computer role-playing games are no exception - all of their thematic elements, stories, characters and fictional environments refer to currently popular (IN) spheres and aspects of the everyday reality, popular leisure activities, tastes and ways of life.

Media culture is an integral part of the current late-modern communication situation. D. Kellner (1995) offers its basic definition by stating that media culture is industrial culture produced for a mass audience, which follows types (genres), conventional formulas, codes, and rules. It is thus a form of commercial culture and its products are also commodities that attract private profit - the accumulation of capital is typical for large media enterprises. The author also points out that media culture is a high-tech culture, which deploys the most advanced technologies and merges culture and technology. This fact complicates, besides influencing other theoretical concepts and issues of media and culture, distinguishing between mainstream media products and artefacts that are meant for alternative (subcultural) groups.

Determination of these distinctions is very problematic because nowadays the mainstream cultural products as well as the forms of alternative culture are produced and disseminated through the exact same production and distribution procedures and communication channels. J. Radošinská and J. Višňovský (2013) see the notion of media culture as semantically more 'neutral' in comparison with the concepts of 'mass culture' and 'popular culture'. The older concept of 'mass culture' has been criticised and rejected by elitist cultural critics since 1940s, mainly for being mass-produced, consumed uncritically and standardised and for having generally low aesthetic and educational potential, (e.g. T. Adorno and M. Horkheimer, 2009; A. Kloskowska, 1967).

On the other hand, various existing understandings of the newer concept of 'popular culture' are based on seeing media audiences as plural, more active, diverse in terms of their preferences and expectations. J. Fiske (2010) sees it as culture of the people, i.e. culture that cannot be produced and is shaped and transformed thanks to the active audiences and their interpretative activities. M. Solík and M. Klementis (2015) also point out that the popular culture is typical for its ambiguity, which is a result of social inequalities in the society.

The term 'media culture' therefore gives us opportunity to address the current development tendencies of media production and distribution processes as well as to discuss the contemporary media audiences, their preferences, expectations and interpretative activities. Since playing video games (especially single-player RPGs which are significantly story-driven) is, without any doubts, an active form of media reception, it seems to be appropriate to reflect on their cultural potential in terms of media culture. The emphasis is placed on the fact that cRPGs are outcomes of the industrially produced culture that aim to satisfy the diverse entertainment needs and expectations of their audiences (players).

M. Solík and M. Klementis (2015) note that cultural products have to offer relevant meanings, which are suitable for 
people belonging to various social groups, in order to become popular. The more levels of meanings such cultural products and forms of entertainment offer, the more likely they will become popular. As we have mentioned above, digital role-playing games are largely based on epic heroic stories. These plots are often complex and compelling enough to be expanded and further developed through so called transmedia narratives. H. Jenkins (2007) says that "transmedia storytelling" represents processes of dispersing the integral elements of a fiction systematically, across multiple delivery channels. The purpose is to create a unified and coordinated entertainment experience. D. Mackay (2003, p. 29) claims that today's role-playing games, films, comic books or paperbacks are inundated by transmedia stories - these "imaginary-entertainment environments" are, in fact, fictional settings that change over time as if they were real and are published in a diverse variety of media products. Each of these products is in communication with the others, expanding the growth, history and status of the original setting of the story.

However, transmedia storytelling cannot be confused with branding or merchandising. Naturally, producers of the most popular digital RPGs aim to offer associated products, game characters, motives or quotes through merchandising products, e.g. T-shirts, action figures, dog tags, mugs, posters and many other kinds of toys, clothes and accessory. Their intention here is to increase the existing economic potential of the original artefact. However, these types of products cannot be defined as transmedia storytelling elements since they do not offer any expansions, prequels, sequels or additions to the original story or stories - they rather use the game's graphic features, characters or quotes in order to sell products that do not extend the story of the game. On the contrary, the elements of transmedia storytelling (books, novels, graphic novels, digital applications, comic books, films, music videos, etc.) stretch the original game's narrative in order to expand the story, whether retrospectively or chronologically.

Many of today's single-player role-playing games explore the possibilities of transmedia storytelling. Their developers and producers, on the one hand, use previously-successful concepts and development methods but, on the other hand, they have to consider new strategies and employ them in accordance with the current trends in media production and promotion of entertaining media content. One of the most successful and critically acclaimed digital RPG series published lately, Dragon Age, may serve as an example of an expanding transmedia universe that includes three major games (Dragon Age: Origins, Dragon Age II and Dragon Age: Inquisition). In terms of sales and profit, the most successful of them is the first one, Dragon Age: Origins, which was sold across three different platforms - PC, X360 and Playstation 3 game consoles. However, the latest (third) installment, Dragon Age: Inquisition, is quite successful too. It is available through five platforms: PC, X360, Playstation 3 and next-gen video game consoles XOne and Playstation 4.

There are also numerous game expansions (DLCs), two guide books which focus on Dragon Age's lore (the fictional world called Thedas and its culture and history), the art book associated with the latest installment of the series, Dragon Age: Inquisition, and hardcover book compilation of Dragon Age comics. The comics (there are six related comic book series) expand the stories of various support characters, explaining their backgrounds, adventures and motivations that were not explained in the three digital games mentioned above. There are also five standalone novels that extend the stories related to the games: Dragon Age: The Stolen Throne, Dragon Age: The Calling, Dragon Age: Asunder, Dragon Age: The Masked Empire and Dragon Age: Last Flight. Some of them can be defined as prequels, telling stories that had happened a long time ago before the adventures and heroic journeys related to the games themselves, other present various forms of parallel storylines happening along with the games' stories.

The universe also includes an anime film titled Dragon Age: Dawn of the Seeker which introduced one of the major characters of Dragon Age: Inquisition, Cassandra Pentaghast. New digital forms of transmedia storytelling are represented by two flash games and one mobile game. The Dragon Age franchise also involves two tabletop RPGs. However, probably the most significant transmedia extensions are two web series: Dragon Age: Warden's Fall and Dragon Age: Redemption. The second one - Redemption - is a live-action web series. As T. Dowd et al. (2013) remark, the six-part series premiered via machinima.com and youtube.com. It was written and starred by Felicia Day who is an avid gamer and a fan-favourite 'youtuber'. BioWare studios and their games' publisher, Electronic Arts, were able to link their brand with Day's in order to perform a clearly successful example of marketing and transmedia storytelling. Moreover, as noted by E. Ellcessor (2014, p. 188-189), though she is not a major Hollywood star, Felicia Day enjoys a subcultural stardom within gamer and "geek" communities. Day's use of social media to promote her own projects has enabled her to be successful, even though this success is situated on the margins of the "traditional" media industry.

If we reflect on digital role-playing games and their position within the system of media culture, it is necessary to point out that these games, once parts of the wider science-fiction and fantasy subculture, have become mainstream media products and widely popular cultural artefacts. The previous examples suggest that the current trends in the media industry refer to the new possibilities of presenting and extending CRPGs through various types of serial narrations and different kinds of media platforms. Applying direct seriality or other previously successful forms of media production and product promotion is, however, also related to different late-modern phenomena, e.g. irony and parody. In H. Pravdová's 
words (2014), the new scientific and scholarly discourse in the areas of gaming activities, functional dimensions of the digital games and game industry principles offers a new space for addressing this issue through philosophy, media and cultural studies, social and cognitive psychology, media sociology or informatics.

\section{Conclusion}

Digital role-playing games are defined as a specific combination of late-modern virtual environments and timeless cultural rituals. Most of their fans and players express a significant amount of interest in literary and film works associated with fantasy and science-fiction genres. The emergence and contemporary popularity of digital RPGs are determined by wider socio-cultural specifics that have been the key parts of the Western world's cultural identity for decades. Digital roleplaying is an opportunity to move within an imaginary symbolic space that represents a new, late-modern manifestation of traditional experience, a new form of cultural expression.

Whether they intend to do so or not, digital role-playing games are able to provide their players with specific sets of values. M. Solík, J. Višňovský and J. Laluhová (2013) state that media products foster different kinds of values: cognitive (epistemological), semantic, heuristic, diagnostic, inspirational, motivational, etc. In addition, M. Solík and J. Mináriková (2014) note that the ideal form of integration of business and media activities would preserve the primary social and cultural mission of the media and the key social challenges related to the media industry.

Most digital role-playing games are (and always have been) based on the elements of science-fiction, fantasy, horror and their various combinations. Each of these forms of modern fantastic fiction is able to activate particularly important and complex aspects of our intrinsic needs and perceptive mechanisms. Fantasy uses archetypes and mythical role models in order to portray heroic journeys and represent the crucial phases of human life, functioning as a secularised neo-spirituality. Science-fiction allows us to explore the relationships between human beings and late-modern technologies within the globalised society that is dependent on its technological sophistication more than ever. It follows that media portrayals of the end of the world, diverse anti-utopic visions of the future or dangerous scientific experiments are very popular and thus are created very frequently. Horror makes us face the unknown, i.e. involves frightening, shocking or repulsive spectacles that are all around us and manifest themselves through our subconscious cognitive and emotional processes. Digital RPGs are also able to appeal to universal as well as individual aspects of our thinking and experience, to reflect on society-wide cultural phenomena by using late-modern experiences and sensations that are, for various reasons, absent in the ordinary life.

\section{List of Acronyms Used in the Text}

CRPG, RPG - (computer) role-playing game, a video game genre that allows the players to control actions of a main character (typically accompanied by various party members) which shape or transform a thoroughly created fictional universe.

DLC - downloadable content, a certain form of digital game expansion, typically published later to add new features, missions or storylines of a video game.

LARP - live action role-playing, a type of role-playing game where the participants physically act out their characters' actions.

MMORPG - massively multiplayer online role-playing game, a kind of multi-player video game that requires Internet connection and involves an extensive virtual environment which allows the players to socially interact and cooperate. laptops).

PC - personal computer, here version of a video game played mostly on personal computers (desktops or

X360, XOne - video game consoles, older and newer version of a gaming device developed by Microsoft.

\section{References}

Adorno T., \& Horkheimer, M. (2009). Dialektika osvícenství. (1st ed.). Praha: OYKOIMENH.

Bowman, S. L. (2010). The Functions of Role-Playing Games: How Participants Create Community, Solve Problems and Explore Identity. (1st ed.). London: McFarland \& Company.

Dowd, T. et al. (2013). Storytelling across Worlds: Transmedia for Creatives and Producers. (1st ed.). Burlington: Focal Press.

Ellcessor, E. (2014). Constructing Social Media's Indie Auteurs: Management of the Celebrity Self in the Case of Felicia Day. In D. Johnson, D. Kompare, \& A. Santo (Eds.), Making Media Work: Cultures of Management in the Entertainment Industries (pp. 188- 
212). New York: New York University Press.

Fiske, J. (2010). Understanding popular culture. (2nd ed.). Abingdon: Routledge.

Gálik, S. (2014). Kyberpriestor ako nová existenciálna dimenzia človeka. Filozoficko-etický pohl'ad. In S. Gálik et al., Kyberpriestor ako nová existenciálna dimenzia človeka (pp. 8-26). Łódź: Księży Młyn Dom Wydawniczy Michał Koliński.

Herec, O. (2008). Z teórie modernej fantastiky. (1st ed.). Bratislava: Literárne informačné centrum.

Jenkins, H. (2004). Game Design as Narrative Architecture. In N. Wardrip-Fruin, \& P. Harrigan (Eds.), First Person: New Media as Story, Performance, and Game (pp. 118-130). Cambridge: MIT Press.

Jenkins, H. (2007). Transmedia Storytelling 101. [Online] Available: http://henryjenkins.org/2007/03/transmedia_storytelling_101.html (September 9, 2015)

Kellner, D. (1995). Media Culture. (1st ed.). London: Routledge.

Kloskowska, A. (1967). Masová kultura (Kritika a obhajoba). (1st ed.). Praha: Nakladatelství Svoboda.

Mackay, D. (2003). Dungeons and Dreamers: The Rise of Computer Game Culture from Geek to Chic. (1st ed.). Emeryville: McGrawHill.

Malíček, J. (2008). Vademecum popkultúry. (1st ed.). Nitra: Univerzita Konštantína Filozofa.

Malíčková, M. (2008). Tematizácia herných modelov filmovým médiom. In J. Malíček (Ed.) et al. Zborník o populárnej kultúre: Popkultúrny hrdina vo virtuálnej realite (pp. 49-83). Nitra: Univerzita Konštantína Filozofa.

McLuhan, M. (2000). Člověk, média a elektronická kultura. (1st ed.). Brno: Jota.

Mortensen, T. E. (2007). Mutual Fantasy Online: Playing With People. In J. Heide Smith, \& P. Williams (Eds.), The Players' Realm: Studies on the Culture of Video Games and Gaming (pp. 188-202). Jefferson: McFarland \& Company.

Pravdová, H., Hudíková, Z., \& Habiňáková, E. (2014). Secularization Process of Homo Medialis. European Journal of Science and Theology, 10(1), 189-197.

Pravdová, H. (2014). Sociokultúrne dimenzie hier v kybernetickom priestore. In S. Gálik et al., Kyberpriestor ako nova existenciálna dimenzia človeka (pp. 132-158). Łódź: Księży Młyn Dom Wydawniczy Michał Koliński.

Radošinská, J., \& Višňovský, J. (2013). Aktuálne trendy v mediálnej kultúre. (1st ed.). Trnava: Fakulta masmediálnej komunikácie UCM.

Solík, M., \& Klementis, M. (2015). Mimicry of Cultural Production for the Majority: Development Tendencies of Mainstream Culture. European Journal of Science and Theology, 11(6), 93-105.

Solík, M., \& Mináriková, J. (2014). Social Recognition on a Global Scale: Opportunities and Limits of Media Reflection. Communication Today, 5(2), 21-31.

Solík, M., Višňovský, J., \& Laluhová, J. (2013). Media as a Tool for Fostering Values in the Contemporary Society. European Journal of Science and Theology, 9(6), 71-77. 